2004s-42 (version révisée/revised version)

\title{
Environmental Regulation and the Eco-industry
}

\author{
Maia David, Bernard Sinclair-Desgagné
}

\begin{tabular}{c}
\hline Série Scientifique \\
Scientific Series
\end{tabular}

Montréal

Septembre 2004

(C) 2004 Maia David, Bernard Sinclair-Desgagné. Tous droits réservés. All rights reserved. Reproduction partielle permise avec citation du document source, incluant la notice $\mathbb{C}$.

Short sections may be quoted without explicit permission, if full credit, including $\mathbb{C}$ notice, is given to the source.
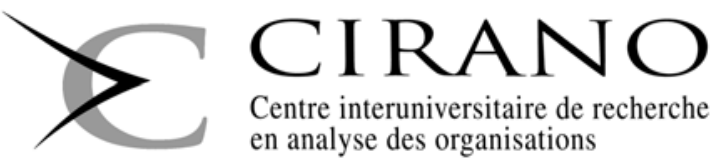

Centre interuniversitaire de recherche

en analyse des organisations 


\section{CIRANO}

Le CIRANO est un organisme sans but lucratif constitué en vertu de la Loi des compagnies du Québec. Le financement de son infrastructure et de ses activités de recherche provient des cotisations de ses organisations-membres, d'une subvention d'infrastructure du Ministère du Développement économique et régional et de la Recherche, de même que des subventions et mandats obtenus par ses équipes de recherche.

CIRANO is a private non-profit organization incorporated under the Québec Companies Act. Its infrastructure and research activities are funded through fees paid by member organizations, an infrastructure grant from the Ministère du Développement économique et régional et de la Recherche, and grants and research mandates obtained by its research teams.

PARTENAIRE MAJEUR

Les organisations-partenaires / The Partner Organizations

. Ministère du Développement économique et régional et de la Recherche [MDERR]

PARTENAIRES

. Alcan inc.

. Axa Canada

. Banque du Canada

. Banque Laurentienne du Canada

. Banque Nationale du Canada

. Banque Royale du Canada

. Bell Canada

. BMO Groupe Financier

. Bombardier

. Bourse de Montréal

. Caisse de dépôt et placement du Québec

. Développement des ressources humaines Canada [DRHC]

. Fédération des caisses Desjardins du Québec

. GazMétro

. Hydro-Québec

. Industrie Canada

. Ministère des Finances du Québec

. Pratt \& Whitney Canada Inc.

. Raymond Chabot Grant Thornton

. Ville de Montréal

. École Polytechnique de Montréal

. HEC Montréal

. Université Concordia

. Université de Montréal

. Université du Québec à Montréal

. Université Laval

. Université McGill

. Université de Sherbrooke

Associe A :

. Institut de Finance Mathématique de Montréal (IFM²)

. Laboratoires universitaires Bell Canada

. Réseau de calcul et de modélisation mathématique $\left[\mathrm{RCM}^{2}\right]$

. Réseau de centres d'excellence MITACS (Les mathématiques des technologies de l'information et des systèmes complexes)

Les cahiers de la série scientifique $(\mathrm{CS})$ visent à rendre accessibles des résultats de recherche effectuée au CIRANO afin de susciter échanges et commentaires. Ces cahiers sont écrits dans le style des publications scientifiques. Les idées et les opinions émises sont sous l'unique responsabilité des auteurs et ne représentent pas nécessairement les positions du CIRANO ou de ses partenaires.

This paper presents research carried out at CIRANO and aims at encouraging discussion and comment. The observations and viewpoints expressed are the sole responsibility of the authors. They do not necessarily represent positions of CIRANO or its partners. 


\title{
Environmental Regulation and the Eco-industry*
}

\author{
Maia David ${ }^{\dagger}$, Bernard Sinclair-Desgagné
}

\begin{abstract}
Résumé / Abstract
Cet article reconsidère la réglementation environnementale, sous l'hypothèse que les technologies et services de réduction de la pollution sont offerts par des entreprises spécialisées formant un oligopole. On y montre que chaque approche réglementaire (taxes et quotas sur les émissions polluantes, normes techniques, ou approches volontaires) a un impact particulier sur l'élasticité-prix de la demande de services en dépollution, donc sur le pouvoir de marché de l'éco-industrie et les coûts de réduction de la pollution. Ceci entraîne, entre autres, qu'une taxe optimale sur les émissions devrait être supérieure au coût marginal des dommages associés à celles-ci, tandis qu'une approche volontaire de réduction des émissions polluantes peut se révéler inopérante si les pratiques de marché de l'éco-industrie ne sont pas elles-mêmes correctement réglementées.
\end{abstract}

Mots clés : régulation de la pollution, réduction en bout de chaîne de la pollution, industries environnementales.

This paper re-examines environmental regulation, under the assumption that pollution abatement technologies and services are provided by an imperfectly competitive environment industry. It is shown that each regulatory instrument (emission taxes and quotas; design standards; and voluntary agreements) has a specific impact on the price-elasticity of the polluters' demand for abatement services, hence on the market power of the eco-industry and the resulting cost of abatement. This implies that the optimal pollution tax will be higher than the marginal cost of pollution damage, while a voluntary approach to pollution abatement may fail unless the eco-industry itself is properly regulated.

Keywords: pollution regulation, end-of-pipe pollution abatement, environment industry.

Codes JEL : H23, L13, Q58

\footnotetext{
* We thank Dominique Bureau, Olivier Godard, Émeric Henry, Nicolas Marchetti, Alain-Désiré Nimubona, Anne Perrot, Gilles Rotillon, and Katheline Schubert for helpful discussions and suggestions. We also acknowledge valuable comments from seminar audiences at HEC Montréal, the University of Paris I, and the University of Toulouse, and the DG-Entreprise of the European Commission in Brussels.

${ }^{\dagger}$ UMR INRA-INAPG Économie publique, Paris, email: mdavid@grignon.inra.fr † Laboratoire d'économétrie de l'École polytechnique, Paris, CIRANO, CIRAIG, and HEC Montréal, Canada, email: $\underline{\text { bsd@hec.ca }}$
} 


\section{Introduction}

Pollution abatement goods and services are now largely supplied by a number of specialized firms. In 1997, these firms totalled earnings of $\$ 350$ billion, and this figure has been projected to double by $2010 .{ }^{1}$ In some countries, such as Germany, France and the Netherlands, their activities account for as much as 2\% of the annual GDP (Barton 1997). Unsurprisingly, the "eco-industry" has then become a major topic for industrial policy and international trade discussions. ${ }^{2}$ It is also central to most government bodies and institutions concerned with environmental regulation. Yet, someone will hardly find in the environmental economics literature an acknowledgement that there even exists such an industry: pollution abatement is consistently assumed to be set only by polluters, based in turn on relevant technological, regulatory or output market considerations, but absent any explicit market or bilateral relationship with actual suppliers. This paper represents a first attempt to fill this gap.

The basic (textbook) framework to analyze pollution abatement can already be viewed as a partial equilibrium model involving a representative price-taking polluter who may procure the needed goods and services on a perfectly competitive market (under no uncer-

\footnotetext{
${ }^{1}$ For additional data, see the reports by the European Commission (1999), the Organization for Economic Cooperation and Development $(1992,1996)$, and the World Trade Organization (1998).

${ }^{2}$ In order to collect reliable data and stimulate rigorous analyses, the OECD and the Statistical Office of the European Commission (Eurostat) have recently developed the following definition of the environment industry (Organization for Economic Cooperation and Development/Eurostat 1999): "The environment industry consists of activities which produce goods and services to measure, prevent, limit, minimize or correct environmental damage to water, air, and soil, as well as problems related to waste, noise and eco-systems. These include cleaner technologies, products and services which reduce environmental risk and minimize pollution and resource use." Note that pollution abatement accounts for more than $80 \%$ of the industry's income (Institut Français de l'Environnement 2002).
} 
tainty, asymmetric information, or capacity constraints). In two companion articles that focus on trade and environmental policy and that first bring in the eco-industry, Feess and Muehlheusser $(1999,2002)$ similarly leave out all strategic actions on the part of environmental service providers. ${ }^{3}$ Several empirical studies reveal, however, that significant segments of the eco-industry, such as waste management, are now dominated by a small number of large suppliers (Barton 1997; Baumol 1995; Davies 2002). These environment firms certainly enjoy some market power and matter to each other. To capture such features, this paper amends the basic framework with the alternative assumption that pollution abatement goods and services are delivered either by a Cournot oligopoly (subsection 4.1) or a monopoly (subsection 4.2 ). ${ }^{4}$ In this context, we find that the particular public policy approach chosen to regulate pollution has a definite influence on the market power of environment firms and on the resulting market price of abatement, through its direct impact on the price-elasticity of demand for pollution-abating services. As a consequence, an optimal pollution tax should be set higher than the marginal social cost of damage (otherwise, the elasticity of demand for pollution abatement would be such

\footnotetext{
${ }^{3}$ These papers' objective is to examine whether tighter environmental regulation may benefit a trading nation. Current wisdom about strategic environmental policy (see, for instance, Barrett 1994) recommends that a tax on emissions be smaller than the marginal social cost of pollution damages (as long as countries compete in quantities and the commodities sold on international markets are strategic substitutes). Feess and Muehlheusser show that the opposite conclusion may hold, however, in the presence of an eco-industry where the production of environmental services is subject to a learning curve.

${ }^{4}$ It might actually have been even more realistic to model the eco-industry as an oligopoly with a competitive fringe, for in most market segments many small and medium enterprises (SMEs) still provide specific equipment and services (World Trade Organization 1998). This would have complicated the presentation, however, without changing our basic message that imperfect competition between abatement technology suppliers is important for environmental regulation.
} 
that the relatively higher prices reached under imperfect competition would generate too little abatement), and a voluntary approach to pollution abatement may be unsuccessful without the eco-industry's willingness to participate.

The following section will now present our model. Section 3 next contains a brief discussion of what first-best production and abatement levels would be. Section 4 - this paper's main section - then turns to environmental regulation and successively considers the two main types of policy instruments - emission-based (i.e., emissions taxes and quotas) and abatement-based (i.e., design standards and voluntary agreements). Section 5 concludes the paper by discussing some possible extensions of the model and future research topics.

\section{The Model}

Before spelling out our model, it is worth recalling a few stylized facts. The eco-industry can be divided into three broad segments: pollution management, cleaner technologies and products, and resources management (WTO 1998; OECD/Eurostat 1999). The first group is by far the most significant in terms of income; it comprises mostly end-of-pipe activities, such as (in decreasing order of importance) solid waste management, waste water treatment, air pollution control, and contaminated soil and groundwater remediation (European Commission 1999). Competition naturally varies within industry segments and countries, but in the United States and Germany for instance, environment firms are generally of a larger size than the national firm average (Barton 1997). ${ }^{5}$ One rationale

\footnotetext{
${ }^{5}$ Ten years ago, for example, Waste Management Technologies already accounted for about $10 \%$ of
} 
for this is that these firms must currently rely heavily on $R \& D$ to compete globally and keep abreast of rapidly evolving environmental regulations. These pieces of information should now fix intuition for the model that follows.

\subsection{Basic Assumptions}

Consider a representative price-taking firm that produces one consumption good while emitting one pollutant. The current price of the consumption good is $P$, and the production cost associated with an output level $x$ is denoted as $C(x)$. This cost function is assumed twice differentiable, strictly increasing and convex.

The firm's emission level is given by the function $e(x, w)$, where $w$ represents abatement effort. This emission function is twice continuously differentiable and such that $e_{x}>0$ (production generates pollution), $e_{w}<0$ (abatement effort reduces pollution), $e_{x x} \geq 0$ (the more the firm produces, the more the last unit delivered pollutes), and $e_{w w}>0$ (there are decreasing returns to abatement). In a manner similar to Barnett (1980), Katsoulacos and Xepapadeas (1995), and Farzin and Kort (2001), for instance, we shall focus on endof-pipe pollution abatement. We therefore assume that $e(x, w)$ is also additively separable, i.e., $e_{x w}=0$, for an investment in end-of-pipe abatement does not modify the production process and so does not affect the amount of pollution imputable to each unit produced. Like Katsoulacos and Xepapadeas (1995), let us suppose, furthermore, that the function $e_{w}(w) w$ is decreasing in $w$, which means that the emission function is not too convex in $w$. All these assumptions would be satisfied if, for example, $e(x, w)=k x-\sqrt{L w}$, where

total eco-industry earnings in the United States and rivaled the aircraft manufacturer Lockheed in size (Karliner 1994). 
$k$ and $L$ are positive real numbers. ${ }^{6}$

\subsection{Enters the Eco-Industry}

Now, let the abatement goods and services be delivered by an eco-industry. An individual supplier $i$ incurs a cost $G\left(w_{i}\right)$ for producing a quantity $w_{i}$ of abatement goods and services, where $G(\cdot)$ is twice differentiable, strictly increasing, convex, and such that $G^{\prime}(0)=0$.

In the simplest setting, the eco-industry is made of $n$ identical firms competing à la Cournot. The case where $n=1$ corresponds to a monopoly, while making $n \rightarrow \infty$ captures perfect competition. The market for abatement is characterized by an inverse demand function $q(w)$, where $w$ stands for total purchases of abatement goods and services. Firm $i$ 's profits are then

$$
\Pi_{i}=q(w) w_{i}-G\left(w_{i}\right), \quad i=1, \ldots, n,
$$

and the first-order condition for profit maximization is precisely $^{7}$

$$
\frac{\partial q}{\partial w} w_{i}+q(w)-G^{\prime}\left(w_{i}\right)=0, \quad i=1, \ldots, n
$$

Since all environment firms are similar, we have that $w_{i}=\frac{w}{n}$ at an equilibrium. ${ }^{8}$ Let

\footnotetext{
${ }^{6}$ Formally, the function $e(x, w)$ could take negative values. However, the quantity of pollution generated by a firm being necessarily positive or equal to zero, we only consider levels of $x$ and $w$ at which $e(x, w)$ is positive. This amounts to suppose that the firm never abates more than it pollutes, which is always true at an equilibrium.

${ }^{7}$ Given our assumptions, first-order conditions are necessary and sufficient wherever they appear.

${ }^{8}$ We suppose that the Cournot-Nash equilibrium exists and is unique. This is ensured when the profit functions $\Pi_{i}$ are concave in $w_{i}$, i.e., when we have $\frac{\partial^{2} q}{\partial w^{2}} w_{i}+2 \frac{\partial q}{\partial w}-G^{\prime \prime} \leq 0$.
} 
$w^{\prime}=\frac{\partial w}{\partial q}$; equation $(1)$ can now be re-written as

$$
q(w)=G^{\prime}\left(w_{i}\right)-\frac{w}{n} \cdot \frac{1}{w^{\prime}}, \quad i=1, \ldots, n
$$

When the number of environment firms $n$ gets large, the price $q$ paid by the polluting firm for each unit of abatement approximates the marginal cost. This is the situation assumed implicitly throughout the environmental economics literature. In general, however, since $w^{\prime}$ is negative (this is proven in section 4), equation (2) reveals that $q(w)>G^{\prime}\left(w_{i}\right)$, so the market price of abatement must exceed the marginal abatement cost. This is a well-known outcome of Cournot competition (or any form of imperfect competition). Also well-known is that the difference between $q(w)$ and $G^{\prime}\left(w_{i}\right)$ - which reflects the environment firms market power - decreases with the price-elasticity of demand for abatement. ${ }^{9}$ We shall soon see how various policy instruments affect this elasticity.

\section{First-Best Abatement}

Abatement efforts are motivated, first of all, by the negative contribution of pollution to social well-being. Without loss of generality, let the level of social prejudice $D$ increase linearly with the amount of emissions, i.e., $D=\nu e(x, w)$ with some positive coefficient $v$. Social welfare is now the sum of consumers' surplus, the polluter's and the eco-industry's

\footnotetext{
${ }^{9}$ Note that $w^{\prime}=\varepsilon \frac{w}{q}$, where $\varepsilon$ denotes the price-elasticity of demand.
} 
profits, and the social damage due to pollution:

$$
W=\int_{0}^{x} P(u) d u-C(x)-q w+q w-n G\left(\frac{w}{n}\right)-v e(x, w) .
$$

The first-order conditions for welfare maximization are then

$$
\begin{aligned}
P\left(x^{*}\right)-C^{\prime}\left(x^{*}\right)-v e_{x}\left(x^{*}\right) & =0, \\
-G^{\prime}\left(\frac{w^{*}}{n}\right)-v e_{w}\left(w^{*}\right) & =0 .
\end{aligned}
$$

According to (4), the price of the consumption good should embed the marginal cost of producing this good plus the marginal social damage associated with it. And according to (5), abatement goods should also be delivered, up to the level $w^{*}$ where the marginal $\operatorname{cost} G^{\prime}\left(\frac{w^{*}}{n}\right)$ of the eco-industry equals the marginal social benefit of abatement $-v e_{w}\left(w^{*}\right)$.

The social welfare objective given by (3), however, makes the eco-industry's revenue and the polluting firm's abatement expenses cancel. All transactions over abatement goods and services were thereby ignored. But if the polluting firm is left to maximize its profits, i.e., to solve

$$
\max _{x, w} \pi=P x-C(x)-q w,
$$

it will surely select the output level $x^{0}$ where the marginal production $\operatorname{cost} C^{\prime}\left(x^{0}\right)$ equals the market price $P$ of the consumption good, while setting its abatement orders at $w^{0}=0$. Without further regulatory intervention, there would therefore be no market for abatement. 


\section{Regulation}

Environmental regulation not only creates a potential market for pollution-abating technologies, it also affects the market power of environment firms. To see this, let us now successively consider some standard policy instruments.

\subsection{Emission-Based Instruments}

Suppose that the regulator introduces a tax $t$ per unit of emission. The profit-maximizing polluter now behaves as if solving

$$
\max _{x, w} \pi^{t}=P x-C(x)-q w-t e(x, w)
$$

so the output and abatement levels will be such that

$$
\begin{aligned}
P-C^{\prime}\left(x^{t}\right)-t e_{x}\left(x^{t}\right) & =0, \\
-q-t e_{w}\left(w^{t}\right) & =0 .
\end{aligned}
$$

To satisfy the latter, the polluting firm is then willing to invest in abatement.

By Cramer's rule, equations (6) and (7) imply that the price-derivative of demand for abating services is precisely

$$
w_{t}^{\prime}=\frac{\partial w^{t}}{\partial q}=-\frac{1}{t e_{w w}} .
$$

Since the second-order derivative $e_{w w}$ is strictly positive, $w_{t}^{\prime}$ is negative; this indicates that, as naturally expected, the polluter's abatement purchases decrease when the price 
of the abating goods and services goes up. The magnitude of $w_{t}^{\prime}$ first depends on the convexity of the emission function with respect to abatement effort: if $e_{w w}$ increases, then $w_{t}^{\prime}$ decreases. This means that, as abatement measures become more effective (at the margin), the polluter's demand for abatement goods and services is less sensitive to their price. What seems important from a policy standpoint, furthermore, is that a larger tax rate $t$ would similarly bring $w_{t}^{\prime}$ closer to zero. In other words: when the tax on pollutant emissions goes up, demand for abatement becomes less price-elastic.

Assuming the regulator is benevolent, the tax level will now be set in order to maximize the following social welfare function:

$W^{t}=\int_{0}^{x^{t}} P(u) d u-C\left(x^{t}\right)-q w^{t}-t e\left(x^{t}, w^{t}\right)+n q \frac{w^{t}}{n}-n G\left(\frac{w^{t}}{n}\right)-v e\left(x^{t}, w^{t}\right)+t e\left(x^{t}, w^{t}\right)$.

Straightforward algebra reduces this expression to ${ }^{10}$

$$
W^{t}=\int_{0}^{x^{t}} P(u) d u-C\left(x^{t}\right)-n G\left(\frac{w^{t}}{n}\right)-v e\left(x^{t}, w^{t}\right)
$$

It can be shown (see the appendix) that the first-order condition for welfare maximization with respect to $t$ then yields

$$
t^{*}=v\left[\frac{e_{x}\left(x^{t}\right) \frac{d x^{t}}{d t}+e_{w}\left(w^{t}\right) \frac{d w^{t}}{d t}}{e_{x}\left(x^{t}\right) \frac{d x^{t}}{d t}+\left[\frac{w^{t} e_{w w}}{n}+e_{w}\left(w^{t}\right)\right] \frac{d w^{t}}{d t}}\right]
$$

\footnotetext{
${ }^{10}$ This simplification amounts, of course, to supposing that tax revenues are transfered and redistributed in a neutral way.
} 
Standard comparative statics via equations (6) and (7) entails that $\frac{d x^{t}}{d t}<0$ and $\frac{d w^{t}}{d t}>0$; the latter's numerator is therefore negative. And since $e_{w}(w) w$ is decreasing by assumption, we have that

$$
\begin{aligned}
w e_{w w}+e_{w}(w) & <0, \\
\text { so } \frac{w^{t} e_{w w}}{n}+e_{w}\left(w^{t}\right) & <0,
\end{aligned}
$$

which implies that the denominator in (9) is also negative. The optimal tax rate is thus positive. Moreover, notice that $\frac{w^{t} e_{w w}}{n} \frac{d w^{t}}{d t}>0$. The coefficient of $\nu$ in the above expression is then greater than 1 , so $t^{*}>v$. This finding constitutes our first proposition.

Proposition 1: When abatement goods and services are supplied by environment firms competing à la Cournot, the optimal pollution tax must be larger than the marginal social damage of emissions.

Observe that, when the number of environment firms $n$ grows, the coefficient of $\nu$ tends to one. ${ }^{11}$ As competition within the eco-industry increases, the optimal tax on emissions then approximates the marginal prejudice caused by the polluting activity. Proposition 1 is therefore consistent with Pigou (1920)'s classical result.

The proposition nevertheless contrasts with several streams of the current literature, notably with the one that postulates an imperfectly competitive polluting industry. Under a polluting monopoly, or when polluting firms are identical and their number is exogenous

\footnotetext{
${ }^{11}$ This conclusion obtains from the presence of the term $\frac{w^{t} e_{w w}}{n}$ in (9). It therefore remains valid if $e_{w w}$ goes to zero instead.
} 
(as in the actual setting), it has indeed been shown that the optimal emission tax falls short of the marginal damage cost (see Buchanan 1969; Barnett 1980; and Katsoulacos and Xepapadeas 1995). ${ }^{12}$ The intuitive rationale for departing from these standard results runs as follows. When the eco-industry is imperfectly competitive, the price of abatement goods and services will be larger than their marginal cost. In this case (comparing equations (5) and (7)), if the tax $t$ was to be set equal to the marginal damage $v$, then the polluter would settle for an abatement level that is too small relative to the first-best $w^{*}$. In order to lessen this distortion, the regulator must then tax pollutant emissions more severely. ${ }^{13}$

In the present context, we can show that a quota on emissions is equivalent to an emission tax, in the sense that it leads to the same output level and abatement expenses. Our analysis of emission-based instruments is then complete. Let us now consider the alternative set of policy instruments.

\subsection{Abatement-Based Instruments}

Abatement-based regulation is sometimes preferred to an approach centered on emissions. It may be difficult, for instance, to precisely measure a polluter's emissions, as in farming and fishing where non-point source pollution is frequent. The regulator would then rely on policy instruments which target the means a potential polluter is commit-

\footnotetext{
${ }^{12}$ Otherwise, the pollution tax would exacerbate the allocative inefficiency (i.e., the under-production) due to imperfect competition. Note that this recommendation can be revised if polluting firms are different or their number is endogenous (Katsoulacos and Xepapadeas 1995; Long and Soubeyran 1999).

${ }^{13}$ As in Buchanan (1969) and Barnett (1980) celebrated work, the optimal tax $t^{*}$ balances the desire to give stronger incentives to abatement with the necessity to limit the contraction of output. Of course, these two distortions could be simultaneously alleviated so that first-best production and abatement levels are implemented if the regulator could combine several policy instruments. This issue is briefly considered in the conclusion of this paper.
} 
ted to take to reduce pollution. This section successively investigates two such instruments: design standards and voluntary agreements. For simplicity, but without impairing our qualitative conclusions, we assume throughout that $n=1$ so the eco-industry is a monopoly.

\subsubsection{Design Standards}

To curtail polluting emissions (of sulfure dioxide, say), the regulator can mandate some specific abatement technologies (such as a particular family of scrubbers). In the present model, this command-and-control approach amounts to impose a given abatement level $\bar{w}$. We suppose that this design standard can be perfectly and costlessly enforced.

In the standard textbook framework, $\bar{w}$ is chosen in order to maximize the social welfare function

$$
W=\int_{0}^{x} P(u) d u-C(x)-q^{D} w+q^{D} w-G(w)-v e(x, w)
$$

with respect to $w$, subject to the polluting industry's willingness to produce and to the polluters' and environment firms' respective profit-maximization conditions

$$
\begin{aligned}
P(x)-C(x)-q w & \geq 0, \\
C^{\prime}(x) & =P, \\
G^{\prime}(w) & =q^{D} .
\end{aligned}
$$


Clearly, the first-best abatement level $w^{*}$ defined in (5) is implemented if it is feasible, but according to (12) the polluting firm produces up to its absolute profit-maximizing level $x^{0}>x^{*}$.

Under a single abatement supplier, however, constraint (13) must be replaced with

$$
\begin{gathered}
q^{D} w-G(w) \geq 0, \text { and } \\
q^{D} \text { maximizes } q w-G(w) \text { subject to (11) and (12), }
\end{gathered}
$$

which respectively capture the environment firm's willingness to participate and profitmaximizing behavior. Provided (14) holds, these new conditions do not affect the regulator's choice of standard or the polluters' production effort, which can respectively remain at $w^{*}$ and $x^{0}$, but (15) entails that the polluters' participation constraint (11) will always be binding. This observation yields a second proposition.

Proposition 2: If the regulator enforces a design standard while abatement goods and services are supplied by a monopoly, then the polluting firms' profits are brought to zero.

This statement tends to explain why mandatory design standards often meet with strong resistance on the part of polluters. The latter would then lobby the regulator so that a price ceiling on abatement goods and services be also enforced or the current policy be simply abandoned. ${ }^{14}$

\footnotetext{
${ }^{14}$ Specific political economy issues raised by the presence of an eco-industry are further discussed in the conclusion of this paper.
} 


\subsubsection{The Voluntary Agreement}

An alternative abatement-based approach that has become quite common over the last decade is the voluntary agreement. In practice, this approach can take various forms (see the OECD 1999 report). The one we shall consider here is often encountered in Europe: the regulator makes the polluter a take-it-or-leave-it offer $w^{V}$ on its abatement level, while threatening to impose an emission tax $\tau$ if this proposal is rejected. ${ }^{15}$

Compared with the design standard, the opportunity the polluter now has to select between achieving a fixed abatement level or being free to choose one under a given pollution tax certainly increases the price-elasticity of demand for abatement and limits the environment firm's market power. If the market price of abatement is too high, the polluting firm can always reduce its orders and submit itself to the emission tax. This inherent flexibility of the voluntary agreement seems to clearly justify its growing popularity and the corresponding decline of command-and-control approaches. But let us examine the situation more carefully.

In the usual textbook setting, the offer $w^{V}$ has to maximize the social welfare function

$$
W^{V}=\int_{0}^{x} P(u) d u-C(x)-G(w)-v e(x, w)
$$

\footnotetext{
${ }^{15}$ Formally, the extensive form of the game is the following. First, the regulator makes an abatement proposal $w^{V}$. Next, polluters accept or refuse the regulator's offer. If they accept, $w^{V}$ is enforced; if not, then the regulator raises a tax $\tau$ per unit of polluting emissions, and the polluters and the eco-industry adjust to it. Subgame perfection requires that $\tau$ be set in order to maximize the regulator's objective $W^{t}=\int_{0}^{x^{t}} P(u) d u-C\left(x^{t}\right)-G\left(w^{t}\right)-v e\left(x^{t}, w^{t}\right)$ with respect to $t$, where $x^{t}$ and $w^{t}$ are determined by the polluters' and the environment firms' respective profit maximization under $t$. Hence, $\tau=v$ when the eco-industry is perfectly competitive, and $\tau=t^{*}$ when it is a Cournot oligopoly.
} 
with respect to $w$, subject to the polluting industry's willingness to accept and to the polluters' and environment firms' respective profit-maximization conditions

$$
\begin{gathered}
P x-C(x)-q^{V} w \geq P x^{\tau}-C\left(x^{\tau}\right)-q^{\tau} w^{\tau}-\tau e\left(x^{\tau}, w^{\tau}\right), \\
C^{\prime}(x)=P, C^{\prime}\left(x^{\tau}\right)+\tau e_{x}\left(x^{\tau}\right)=P,-\tau e_{w}\left(w^{\tau}\right)=q^{\tau}, \\
G^{\prime}(w)=q^{V}, G^{\prime}\left(w^{\tau}\right)=q^{\tau} .
\end{gathered}
$$

Again, we have that the polluters' output $x^{V}=x^{0}$, so as much of the consumption good is produced as in a situation with no environmental regulation. Notice, however, that the right-hand side of (17) is greater than or equal to zero, so the regulator's choice set can be smaller than under command-and-control. This may not allow the first-best abatement level $w^{*}$ to be implemented voluntarily.

If the eco-industry is a monopoly, however, the incentive constraint (19) changes into

$$
\begin{gathered}
q^{V} \text { maximizes } \Pi^{V}=q w-G(w) \text { subject to (11) and (18), and } \\
q^{\tau} \text { maximizes } \Pi^{\tau}=q w^{\tau}-G\left(w^{\tau}\right) \text { subject to (11) and (18). }
\end{gathered}
$$

On the one hand, condition (21) relaxes the participation constraint (17) by decreasing the value of its right-hand side. This reflects that an emission tax now constitutes a stronger threat, which leaves the regulator greater chances to achieve $w^{*}$. On the other hand, the monopolistic price $q^{V}$ set under (20) will usually be so high as to violate (17) 
and deter any agreement with the regulator. To fix this, the latter may authorize polluters to renege on a promised abatement level if the environment firm charges too high a price. The following conditions must then substitute for condition (20):

$$
\begin{gathered}
q^{V} \text { maximizes } \Pi^{V}=q w-G(w) \text { subject to }(17) \text { and (18), and } \\
\Pi^{V} \geq \Pi^{\tau} .
\end{gathered}
$$

According to these, the environment firm will maximize its profits without jeopardizing the voluntary scheme (condition $\left(20^{\prime}\right)$ ), provided it is better off under this scheme than under an emission tax (condition (22)). This conclusion supports our last proposition.

Proposition 3. In the presence of a monopolistic eco-industry, a voluntary agreement is feasible only if the environment firm is also willing to participate.

Clearly, under $\left(20^{\prime}\right)$ the participation constraint (17) will be binding, so polluters end up being indifferent between accepting the regulator's proposal or opting for the emission tax. As opposed to the command-and-control situation, however, the polluters' profits may now be strictly positive.

\section{Concluding Remarks}

Prices polluters pay to alleviate environmental damages are currently often determined on market segments dominated by a few large suppliers of abatement technologies. While this fact is widely acknowledged in environmental policy discussions, environmental economics still provides little guidance on how to precisely regulate polluting activities in this context. 
This paper first seeked to convey the message that imperfect competition between environment firms does matter for environmental regulation. Accordingly, we amended the basic (textbook) setting - which involves a representative price-taking polluter and no uncertainty or asymmetric information - by now making the polluting firm acquire abatement goods and services from only one supplier or from many identical suppliers competing à la Cournot. We then showed that taxes on emissions would have to be adjusted upward, and that a voluntary agreement on abatement efforts may not be doable if the eco-industry is reluctant to support it.

The present analysis could be extended in various ways. Other policy instruments - such as abatement subsidies, tradable emission permits, performance standards, and different voluntary schemes - should be considered. Additional segments of the environment industry (cleaner technologies and product; ressources management) could be brought in (at the cost of dropping our assumption that the emission function $e(x, w)$ is additively separable). There could be imperfect competition between polluters as well. ${ }^{16}$ Other modes of competition than Cournot could be studied. Entry and exit in the end product sector and in the eco-industry could be made endogenous. Polluting and environment firms could be heterogenous. And environment firms could be endowed with private information about the cost (or the quality) of their abatement goods and services. ${ }^{17}$

\footnotetext{
${ }^{16}$ Intuitively, since Cournot competition between polluters and between abatement suppliers entails that optimal emission taxes are respectively lower and higher than the marginal social cost of pollution damage, simultaneous Cournot competition in both the product and the abatement industries would bring such taxes closer to the Pigouvian level. A formal demonstration of this can be found in Nimubona and Sinclair-Desgagné (2005).

${ }^{17}$ This extension may not constitute a straightforward application of the actual literature on vertical
} 
This paper has focused on the specific form to be taken by some environmental policy instruments in the presence of an oligopolistic eco-industry. An immediate research direction from here would be the comparison of regulatory approaches. At this point, it can be said that when the market for abatement goods and services is perfectly competitive, the optimal emission tax implements the first-best, while a voluntary approach to pollution abatement remains a second-best instrument (because the output $x^{0}$ chosen by a polluter is larger than the socially optimal level). When the eco-industry is imperfectly competitive and exercises market power, however, taxing pollution also becomes a second-best policy. Moreover, we have that $w^{*} \geq w^{V}>w^{t^{*}}$ and $x^{0}=x^{V}>x^{t^{*}}$; so the abatement level achieved through a voluntary agreement is higher than the one reachable via a pollution tax (it can even attain the first-best), but the amount of the consumption good produced under a voluntary agreement exceeds the first-best one. It is thus impossible to rank, for all existing cases, an emission tax or quota above or below a voluntary agreement in terms of social welfare. Yet, an unambiguous ranking of policy instruments can be found for specialized versions of the present model..$^{18}$

Related to this topic is the appropriate combination of policy instruments to correct simultaneously for the pollution externality and the output distortion due to imperfect

relationships and outsourcing (see, for instance, Perry 1989; or Mookherjee 2003), for the abatement services provided by environment firms are meant to correct a negative externality and are often not embedded in the consumption good.

\footnotetext{
${ }^{18}$ For example, using the functions $P(x)=1-x, C(x)=\frac{1}{2} x^{2}, G(w)=g w(g>0)$, and $e(x, w)=$ $k x-\sqrt{L w}(k>0, L>0)$, where the parameter $g$ represents the marginal production cost of the ecoindustry, $k$ is the amount of emissions generated by one unit of the consumption good, and $L$ captures the efficiency of the available abatement goods and services. Computations can be obtained from the authors upon request.
} 
competition. To be sure, imposing a standard $w^{*}$ together with an emission tax that brings about an output level $x^{*}$ would achieve the first-best. But as argued by Carraro and Metcalf (2001), administrative costs and political constraints may leave regulators with an incomplete set of instruments to choose from. Moreover, policy coordination between various government bodies (the environmental protection and antitrust agencies, for example) is often far from guaranteed and deserves closer scrutiny.

In practice, the design of environmental policy is also subject to pressures from public opinion and industrial lobbies. ${ }^{19}$ The latter are now likely to include some powerful environment firms. Complete theoretical analysis of the political economy of environmental regulation should therefore try to capture the eco-industry's influence in regulatory decisions. The upshot might exhibit some mixed intervention strategies of the type studied by Cadot and Sinclair-Desgagné (1995), which balance the interests of polluters for lower compliance costs with those of environmental firms for greater needs of their specific goods and services.

Finally, renewed attention should be given to the effect of environmental policy on technological change, taking into account the specific role played by the eco-industry. ${ }^{20}$ The relative advantage of market-based instruments over direct regulation in providing incentives to adopt new technologies might have to be revised downward, as the desire of competing environment firms to innovate might be enhanced, for instance, under "Best

\footnotetext{
${ }^{19}$ See, for instance, Boyer and Laffont (1999), and the essays collected in Stavins (2004).

${ }^{20} \mathrm{Jaffe}$ et al. (2002) provide a good survey of the issues and contributions pertaining to environmental regulation and technological change.
} 
Available Control Technology" regulations. The eco-industry might also bring down the cost of technological updating (through the learning-curve effect pointed out by Feess, E., and G. Muehlheusser (2002), for example) and benefit from spreading new standards and know-how, thereby accelerating the diffusion of cleaner technologies.

\section{Appendix: The Optimal Pollution Tax - Equation (9)}

Total differentiation of $W^{t}$ yields:

$$
\frac{d W^{t}}{d t}=\left[P\left(x^{t}\right)-C^{\prime}\left(x^{t}\right)\right] \frac{d x^{t}}{d t}-G^{\prime}\left(\frac{w^{t}}{n}\right) \frac{d w^{t}}{d t}-v\left[e_{x}\left(x^{t}\right) \frac{d x^{t}}{d t}+e_{w}\left(w^{t}\right) \frac{d w^{t}}{d t}\right] .
$$

Since, by (5) and (6),

$$
-G^{\prime}\left(\frac{w^{t}}{n}\right)=-q\left(w^{t}\right)-\frac{w^{t}}{n} \cdot \frac{1}{w_{t}^{\prime}} \text { and } P-C^{\prime}\left(x^{t}\right)=t e_{x}\left(x^{t}\right)
$$

(A.1) is equivalent to:

$$
\frac{d W^{t}}{d t}=t e_{x}\left(x^{t}\right) \frac{d x^{t}}{d t}+\left[-q\left(w^{t}\right)-\frac{w^{t}}{w_{t}^{\prime}} \cdot \frac{1}{n}\right] \frac{d w^{t}}{d t}-v\left[e_{x}\left(x^{t}\right) \frac{d x^{t}}{d t}+e_{w}\left(w^{t}\right) \frac{d w^{t}}{d t}\right] .
$$

Recalling from (7) and (8) that $-q\left(w^{t}\right)=t e_{w}\left(w^{t}\right)$ and $-\frac{w^{t}}{w_{t}^{t}}=w^{t} t e_{w w}$, (A.2) now becomes

$$
\frac{d W^{t}}{d t}=t e_{x}\left(x^{t}\right) \frac{d x^{t}}{d t}+\left[e_{w}\left(w^{t}\right)+\frac{w^{t} e_{w w}}{n}\right] t \frac{d w^{t}}{d t}-v\left[e_{x}\left(x^{t}\right) \frac{d x^{t}}{d t}+e_{w}\left(w^{t}\right) \frac{d w^{t}}{d t}\right] .
$$

Setting the latter equal to 0 gives equation (9). 


\section{References}

Barnett, A. H. 1980. "The Pigouvian Tax Rule under Monopoly." American Economic Review 70: 1037-1041.

Barrett, S. 1994. "Strategic Environmental Policy and International Trade." Journal of Public Economics 54: 325-358.

Barton, J. R. 1997. "The North-South Dimension of the Environment and Cleaner Technology Industries." Discussion Paper no. 9803, Institute for New Technologies, United Nations University, Maastricht, The Netherlands.

Baumol, W. J. 1995. "Environmental Industries with Substantial Start-Up Costs as Contributors to Trade Competitiveness." Annual Review of Energy and the Environment 20: $71-81$.

Boyer, M., and J.-J. Laffont. 1999. "Toward a Political Theory of the Emergence of Environmental Incentive Regulation," Rand Journal of Economics 30: 137-157.

Buchanan, J. M. 1969. "External Diseconomies, Corrective Taxes, and Market Structure." American Economic Review 59(1): 174-177.

Cadot, O., and B. Sinclair-Desgagné. 1995. "Environmental Standards and Industrial Policy." Journal of Environmental Economics and Management 29: 228-237.

Carraro, C., and G. E. Metcalf. 2001. Behavioral and Distributional Effects of Environmental Policy. NBER Conference Reports, University of Chicago Press.

Davies, S. 2002. "Waste Management Multinationals 2002." Mimeo, Public Services International research Unit (PSIRU), School of Computing and Mathematical Sciences, University of Greenwich.

European Commission. 1999. "The EU Ecoindustry's Export Potential: Final Report to DGXI of the European Commission." Brussels.

Farzin, H., and P. Kort. 2001. "Pollution Abatement Investment when Environmental Regulation Is Uncertain." Journal of Public Economic Theory 2(2): 183-212.

Feess, E., and G. Muehlheusser. 2002. "Strategic Environmental Policy, Clean Technologies and the Learning Curve." Environmental and Resource Economics 23: 149-166.

Feess, E., and G. Muehlheusser. 1999. "Strategic Environmental Policy, International Trade and the Learning Curve: The Significance of the Environmental Industry." Review of Economics 50 (2): 178-194.

Jaffe, A., R. G. Newell, and R. N. Stavins. 2002. "Technological Change and the Environment." Chapter 11 in Handbook of Environmental Economics, Vol. I, edited by K.-G. Mähler and J. R. Vincent. Amsterdam: Elsevier Science.

Institut Français de l'Environnement (IFEN). 2002. L'environnement en France. Paris: Éditions La Découverte. 
Katsoulacos, Y., and A. Xepapadeas. 1995. "Environmental Policy under Oligopoly with Endogenous Market Structure." Scandinavian Journal of Economics 97(3): 411-420.

Karliner, J. 1994. "The Environment Industry: Profiting from Pollution." The Ecologist 24(2): 59-63.

Long, N. V., and A. Soubeyran. 1999. "Pollution, Pigouvian Taxes, and Asymmetric International Oligopoly." CIRANO Working Paper, Montréal.

Mookherjee, D. 2003. "Delegation and Contracting Hierarchies: An Overview." Mimeo, Boston University.

Nimubona, A.-D., and B. Sinclair-Desgagné. 2005. "The Pigouvian Tax Rule in the Presence of an Eco-Industry." Mimeo, HEC Montréal.

Organization for Economic Cooperation and Development/Eurostat. 1999. The Environmental and Services Industry: Manual for Data Collection and Analysis. Paris: OECD Editions.

Organization for Economic Cooperation and Development. 1999. Voluntary Approaches to Environmental Policies: An Assessment. Paris: OECD Editions.

Organization for Economic Cooperation and Development. 1996. The Global Environmental Goods and Services Industry. Paris: OECD Editions.

Organization for Economic Cooperation and Development. 1992. The Environmental Industry in OECD Countries: Situation, Perspectives and Governmental Policies. Paris: OECD Editions.

Perry, M. K. 1989. "Vertical Integration: Determinants and Effects." In Handbook of Industrial Organization, Vol. I, edited by R. Schmalensee and R. D. Willig. Amsterdam: North Holland.

Pigou, A. C. 1920. The Economics of Welfare. London: Macmillan.

Stavins, R. N. (ed.). 2004. The Political Economy of Environmental Regulation. Edwar Elgar Publishing.

World Trade Organization. 1998. "Environmental Services." Chapter IX of the Committee on Trade and Environment's Note on "Environmental Benefits of Removing Trade Restrictions and Distortions." 